\title{
Detection of Severe Acute Respiratory Syndrome Coronavirus 2 RNA on Surfaces in Quarantine Rooms
}

\author{
Fa-Chun Jiang, ${ }^{1}$ Xiao-Lin Jiang, ${ }^{1}$ Zhao-Guo Wang, Zhao-Hai Meng, \\ Shou-Feng Shao, Benjamin D. Anderson, Mai-Juan Ma
}

We investigated severe acute respiratory syndrome coronavirus 2 (SARS-CoV-2) environmental contamination in 2 rooms of a quarantine hotel after 2 presymptomatic persons who stayed there were laboratory-confirmed as having coronavirus disease. We detected SARS-CoV-2 RNA on $8(36 \%)$ of 22 surfaces, as well as on the pillow cover, sheet, and duvet cover.

Cevere acute respiratory syndrome coronavirus 2 $\checkmark$ (SARS-CoV-2) has rapidly spread globally and, as of May 2, 2020, had caused $>3$ million confirmed coronavirus disease cases (1). Although SARS-CoV-2 transmission through respiratory droplets and direct contact is clear, the potential for transmission through contact with surfaces or objects contaminated with SARS-CoV-2 is poorly understood (2). The virus can be detected on various surfaces in the contaminated environment from symptomatic and paucisymptomatic patients $(3,4)$. Moreover, we recently reported detection of SARS-CoV-2 RNA on environmental surfaces of a symptomatic patient's household (5). Because SARS-CoV-2 remains viable and infectious from hours to days on surfaces $(6,7)$, contact with a contaminated surface potentially could be a medium for virus transmission. In addition, high viral load in throat swab specimens at symptom onset $(8,9)$ and peak infectiousness at 0-2 days for presymptomatic

Author affiliations: Qingdao Municipal Center for Disease Control and Prevention, Qingdao, China (F.-C. Jiang, Z.-G. Wang,

Z.-H. Meng, S.-F. Shao); Shandong Provincial Center for Disease Control and Prevention, Jinan, China (X.-L. Jiang); Global Health Research Center, Duke Kunshan University, Kunshan, China (B.D. Anderson); State Key Laboratory of Pathogen and Biosecurity, Beijing Institute of Microbiology and Epidemiology, Beijing, China (M.-J. Ma)

DOI: https://doi.org/10.3201/eid2609.201435 patients (8) suggest that presymptomatic patients may easily contaminate the environment. However, data are limited on environmental contamination of SARS-CoV-2 by patients who may be presymptomatic. Therefore, to test this hypothesis, we examined the presence of SARS-CoV-2 RNA in collected environmental surface swab specimens from 2 rooms of a centralized quarantine hotel where 2 presymptomatic patients had stayed.

\section{The Study}

Two Chinese students studying overseas returned to China on March 19 (patient A) and March 20 (patient B), 2020 (Table 1). On the day of their arrival in China, neither had fever or clinical symptoms, and they were transferred to a hotel for a 14-day quarantine. They had normal body temperatures (patient A, $36.3^{\circ} \mathrm{C}$; patient $\mathrm{B}, 36.5^{\circ} \mathrm{C}$ ) and no symptoms when they checked into the hotel. During the quarantine period, local medical staff were to monitor their body temperature and symptoms each morning and afternoon. On the morning of the second day of quarantine, they had no fever (patient $\mathrm{A}, 36.2^{\circ} \mathrm{C}$; patient $\mathrm{B}$, $36.7^{\circ} \mathrm{C}$ ) or symptoms. At the same time their temperatures were taken, throat swab samples were collected; both tested positive for SARS-CoV-2 RNA by real-time reverse transcription PCR (rRT-PCR). The students were transferred to a local hospital for treatment. At admission, they remained presymptomatic, but nasopharyngeal swab, sputum, and fecal samples were positive for SARS-CoV-2 RNA with high viral loads (Table 1$)$. In patient $A$, fever $\left(37.5^{\circ} \mathrm{C}\right)$ and cough developed on day 2 of hospitalization, but his chest computed tomography images showed no significant abnormality during hospitalization. In patient $\mathrm{B}$, fever $\left(37.9^{\circ} \mathrm{C}\right)$ and cough developed on day 6 of

${ }^{1}$ These authors contributed equally to this article. 
Table 1. Timeline from return to China by 2 persons with presymptomatic SARS-CoV-2 infection to results of environmental sampling of their rooms at a centralized quarantine hotel, $2020^{*}$

\begin{tabular}{|c|c|c|}
\hline Characteristic & Patient A & Patient B \\
\hline Date returned to China & $19 \mathrm{Mar}$ & $20 \mathrm{Mar}$ \\
\hline Date entered quarantine & $19 \mathrm{Mar}$ & $21 \mathrm{Mar}$ \\
\hline $\begin{array}{l}\text { Date of SARS-CoV-2 } \\
\text { RNA-positive detection }\end{array}$ & $20 \mathrm{Mar}$ & $22 \mathrm{Mar}$ \\
\hline $\begin{array}{l}\text { Date of environmental } \\
\text { surface sampling }\end{array}$ & $20 \mathrm{Mar}$ & $22 \mathrm{Mar}$ \\
\hline $\begin{array}{l}\text { Symptoms at hospital } \\
\text { admission }\end{array}$ & None & None \\
\hline \multicolumn{3}{|c|}{$\mathrm{C}_{\mathrm{t}}$ for clinical samples at admissiont } \\
\hline Nasopharyngeal swab & 24.72 & 27.87 \\
\hline Sputum & 28.61 & 23.23 \\
\hline Fecal swab & 33.12 & NA \\
\hline $\begin{array}{l}\text { Symptoms during } \\
\text { hospitalization }\end{array}$ & $\begin{array}{l}\text { Fever, chills, } \\
\text { cough }\end{array}$ & $\begin{array}{c}\text { Fever, cough, } \\
\text { sputum, sore } \\
\text { throat }\end{array}$ \\
\hline Disease severity & Mild & Moderate \\
\hline
\end{tabular}

${ }^{*} \mathrm{C}_{\mathrm{t}}$, cycle threshold; NA, not available; rRT-PCR, real-time reverse transcription PCR; SARS-CoV-2, severe acute respiratory syndrome coronavirus 2.

tA lower $\mathrm{C}_{t}$ indicates a higher viral load. Only $\mathrm{C}_{t}$ values for open reading frame1ab (ORFab1) gene of SARS-CoV-2 were provided in the table because the $\mathrm{Ct}$ values for nucleoprotein were similar to values of ORFab1.

hospitalization, and her computed tomography images showed ground-glass opacities.

Approximately 3 hours after the 2 patients were identified as positive for SARS-CoV-2 RNA, we sampled the environmental surfaces of the 2 rooms in the centralized quarantine hotel in which they had stayed. Because of the SARS-CoV-2 outbreak in China, the hotel had been closed during January 24-March 18, 2020. Therefore, only these 2 persons had stayed in the rooms. We used a sterile polyester-tipped applicator, premoistened in viral transport medium, to sample the surfaces of the door handle, light switch, faucet handle, thermometer, television remote, pillow cover, duvet cover, sheet, towel, bathroom door handle, and toilet seat and flushing button. We also collected control swab samples from 1 unoccupied room. We collected each sample by swabbing each individual surface. We tested the samples with an rRT-PCR test kit (DAAN GENE Ltd, http://www.daangene.com) targeting the open reading frame $1 \mathrm{ab}(\mathrm{ORF1} \mathrm{ab})$ and $N$ genes of SARS-CoV-2. We interpreted cycle threshold $\left(C_{t}\right)<40$ as positive for SARS-CoV-2 RNA and $C_{t} \geq 40$ as negative.

We collected a total of 22 samples from the 2 rooms of the quarantine hotel (Table 2). Eight (36\%) samples were positive for SARS-CoV-2 RNA. C $C_{t}$ values ranged from 28.75 to 37.59 (median 35.64). Six $(55 \%)$ of 11 samples collected from the room of patient A were positive for SARS-CoV-2 RNA. Surface samples collected from the sheet, duvet cover, pillow cover, and towel tested positive for SARS-CoV-2

RNA, and surface samples collected from the pillow cover and sheet had a high viral load; $\mathrm{C}_{t}$ for ORF1ab gene from the pillow cover was 28.97 and from the sheet, 30.58. Moreover, the $C_{t}$ values of these 2 samples correlated with those of patient A's nasopharyngeal (24.73) and fecal (33.12) swab samples at hospital admission. One surface sample from the faucet in patient B's room was positive for SARS-CoV-2 RNA; the $C_{t}$ was 28.75 for the ORF1ab gene. Again, we detected SARS-CoV-2 RNA from the surface samples of the pillow cover; $C_{t}$ was 34.57. All control swab samples were negative for SARS-CoV-2 RNA.

\section{Conclusions}

Our study demonstrates extensive environmental contamination of SARS-CoV-2 RNA in a relatively short time ( $<24$ hours) in occupied rooms of 2 persons who were presymptomatic. We also detected SARSCoV-2 RNA in the surface swab samples of the pillow cover, duvet cover, and sheet.

Evidence for SARS-CoV-2 transmission by indirect contact was identified in a cluster of infections at a shopping mall in China (10). However, no clear evidence of infection caused by contact with the contaminated environment was found. SARS-CoV-2 RNA has been detected on environmental surfaces in isolation rooms where the symptomatic or paucisymptomatic patients stayed for several days (3-5). In our study, we demonstrate high viral load shedding in presymptomatic patients, which is consistent with previous studies $(8,9)$, providing further evidence for the presymptomatic transmission of the virus (5,11-15).

\begin{tabular}{|c|c|c|}
\hline \multirow[b]{2}{*}{ Environmental source $†$} & \multicolumn{2}{|c|}{ Values $\ddagger$} \\
\hline & Patient A's room & Patient B's room \\
\hline Door handle & $0 / 1$ & $0 / 1$ \\
\hline Light switch & 1/1 (37.59) & $0 / 1$ \\
\hline Faucet & $0 / 1$ & 1/1 (28.75) \\
\hline Bathroom door handle & $1 / 1(36.02)$ & $0 / 1$ \\
\hline Toilet seat, flush handle & $0 / 1$ & $0 / 1$ \\
\hline Thermometer & $0 / 1$ & $0 / 1$ \\
\hline TV remote & $0 / 1$ & $0 / 1$ \\
\hline Pillow cover & $1 / 1(28.98)$ & $1 / 1(34.57)$ \\
\hline Duvet cover & $1 / 1(35.64)$ & $0 / 1$ \\
\hline Sheet & $1 / 1(30.58)$ & $0 / 1$ \\
\hline Towel & $1 / 1(36.98)$ & $0 / 1$ \\
\hline Total, no. (\%) & $6 / 11(54.5)$ & $2 / 11(18.2)$ \\
\hline \multicolumn{3}{|c|}{$\begin{array}{l}{ }^{*} \text { Values are no. positive/total }\left(C_{t}\right) \text { except as indicated. } C_{t} \text {, cycle threshold; } \\
\text { rRT-PCR, real-time reverse transcription PCR; SARS-CoV-2, severe acute } \\
\text { respiratory syndrome coronavirus } 2 \text {. } \\
\text { tOne swab was taken from each site except the light switch, from which } 2 \\
\text { swabs were taken. } \\
\text { fAll samples taken from patients A and B after disinfection were negative } \\
\text { and not included in this table. A lower } C_{t} \text { indicates a higher viral load. Only } \\
C_{t} \text { values for open reading frame } 1 \text { ab (ORFab1) gene of SARS-CoV-2 } \\
\text { were provided because the } C_{t} \text { values for nucleoprotein were similar to } \\
\text { those of ORFab1. }\end{array}$} \\
\hline
\end{tabular}

Table 2. Results of environmental sampling of 2 rooms at a centralized quarantine hotel occupied by 2 presymptomatic SARS-CoV-2-infected patients, China, 2020* 
In addition, presymptomatic patients with high viral load shedding can easily contaminate the environment in a short period.

Our results also indicate a higher viral load detected after prolonged contact with sheets and pillow covers than with intermittent contact with the door handle and light switch. The detection of SARSCoV-2 RNA in the surface samples of the sheet, duvet cover, and pillow cover highlights the importance of proper handling procedures when changing or laundering used linens of SARS-CoV-2 patients. Thus, to minimize the possibility of dispersing virus through the air, we recommend that used linens not be shaken upon removal and that laundered items be thoroughly cleaned and dried to prevent additional spread.

The absence of viral isolation in our investigation was an obstacle to demonstrating the infectivity of the virus, but SARS-CoV-2 has been reported to remain viable on surfaces of plastic and stainless steel for up to 4-7 days $(6,7)$ and 1 day for treated cloth (7). In summary, our study demonstrates that presymptomatic patients have high viral load shedding and can easily contaminate environments. Our data also reaffirm the potential role of surface contamination in the transmission of SARS-CoV-2 and the importance of strict surface hygiene practices, including regarding linens of SARS-CoV-2 patients.

This work was supported by the National Major Project for Control and Prevention of Infectious Disease of China (2017ZX10303401-006), the National Natural Science Foundation of China (81773494 and 81621005), and the Special National Project on investigation of basic resources of China (2019FY101502).

\section{About the Author}

Dr. Jiang is an epidemiologist in Qingdao Center for Disease Control and Prevention, Qingdao, Shandong Province, China. His primary research interests included infectious disease control and prevention and emerging infectious diseases.

\section{References}

1. World Health Organization. Coronavirus disease (COVID-19). Situation report-102 [cited 2020 May 1]. https://www.who.int/docs/default-source/coronaviruse/ situation-reports/20200501-covid-19-sitrep.pdf

2. Centers for Disease Control and Prevention. Coronavirus disease 2019 (COVID-19). How COVID-19 spreads [cited 2020 May 2]. https:/ / www.cdc.gov/coronavirus/2019-ncov/ prevent-getting-sick/how-covid-spreads.html

3. Ong SWX, Tan YK, Chia PY, Lee TH, Ng OT, Wong MSY, et al. Air, surface environmental, and personal protective equipment contamination by severe acute respiratory syndrome coronavirus 2 (SARS-CoV-2) from a symptomatic patient. JAMA. 2020;323:1610. https://doi.org/10.1001/ jama.2020.3227

4. Yung CF, Kam KQ, Wong MSY, Maiwald M, Tan YK, $\mathrm{Tan} \mathrm{BH}$, et al. Environment and personal protective equipment tests for SARS-CoV-2 in the isolation room of an infant with infection. Ann Intern Med. 2020 Apr 1 [Epub ahead of print]. PubMed https://doi.org/10.7326/M20-0942

5. Jiang XL, Zhang XL, Zhao XN, Li CB, Lei J, Kou ZQ, et al. Transmission potential of asymptomatic and paucisymptomatic SARS-CoV-2 infections: a three-family cluster study in China. J Infect Dis. 2020 Apr 22 [Epub ahead of print]. https://doi.org/10.1093/infdis/jiaa206

6. van Doremalen N, Bushmaker T, Morris DH, Holbrook MG, Gamble A, Williamson BN, et al. Aerosol and surface stability of SARS-CoV-2 as compared with SARS-CoV-1. N Engl J Med. 2020;382:1564-7. https:/ / doi.org/10.1056/ NEJMc2004973

7. Chin AWH, Chu JTS, Perera MRA, Hui KPY, Yen H-L, Chan MCW, et al. Stability of SARS-CoV-2 in different environmental conditions. Lancet Microbe. 2020;1:e10. https://doi.org/10.1016/S2666-5247(20)30003-3

8. He X, Lau EHY, Wu P, Deng X, Wang J, Hao X, et al. Temporal dynamics in viral shedding and transmissibility of COVID-19. Nat Med. 2020 Apr 15 [Epub ahead of print]. https://doi.org/10.1038/s41591-020-0869-5

9. Wölfel R, Corman VM, Guggemos W, Seilmaier M, Zange S, Müller MA, et al. Virological assessment of hospitalized patients with COVID-2019. Nature. 2020 Apr 1 [Epub ahead of print]. https://doi.org/10.1038/ s41586-020-2196-x

10. Cai J, Sun W, Huang J, Gamber M, Wu J, He G. Indirect virus transmission in cluster of COVID-19 cases, Wenzhou, China, 2020. Emerg Infect Dis. 2020 Mar 12[Epub ahead of print]. https://doi.org/10.3201/eid2606.200412

11. Rothe C, Schunk M, Sothmann P, Bretzel G, Froeschl G, Wallrauch C, et al. Transmission of 2019-nCoV infection from an asymptomatic contact in Germany. N Engl J Med. 2020;382:970-1. https:/ / doi.org/10.1056/NEJMc2001468

12. Yu P, Zhu J, Zhang Z, Han Y. A familial cluster of infection associated with the 2019 novel coronavirus indicating potential person-to-person transmission during the incubation period. J Infect Dis. 2020;221:1757-61. https://doi.org/10.1093/infdis/jiaa077

13. Tong ZD, Tang A, Li KF, Li P, Wang HL, Yi JP, et al. Potential presymptomatic transmission of SARS-CoV-2, Zhejiang province, China, 2020. Emerg Infect Dis. 2020;26:1052-4. https:/ / doi.org/10.3201/eid2605.200198

14. Wei WE, Li Z, Chiew CJ, Yong SE, Toh MP, Lee VJ. Presymptomatic transmission of SARS-CoV-2 - Singapore, January 23-March 16, 2020. MMWR Morb Mortal Wkly Rep. 2020;69:411-5. https:/ / doi.org/10.15585/mmwr.mm6914e1

15. Kimball A, Hatfield KM, Arons M, James A, Taylor J, Spicer K, et al.; Public Health-Seattle \& King County; CDC COVID-19 Investigation Team. Asymptomatic and presymptomatic SARS-CoV-2 infections in residents of a long-term care skilled nursing facility - King County, Washington, March 2020. MMWR Morb Mortal Wkly Rep. 2020;69:377-81. https://doi.org/10.15585/mmwr.mm6913e1

Address for correspondence: Mai-Juan Ma, State Key Laboratory of Pathogen and Biosecurity, Beijing Institute of Microbiology and Epidemiology, No. 20, Dongdajie St., Fengtai District, Beijing 100071, China; email: mjma@163.com 